DOI:

Volume 10 Nomor 22017

\title{
EVALUATING THE EFFECTIVENESS OF DUAL MONETARY POLICY IN PROMOTING PRICE STABILITY IN INDONESIA
}

\section{Arif Widodo}

Centre for Development of Islamic Economics and Finance, Universitas Muhammadiyah Yogyakarta

rifdoisme@gmail.com

\section{Abstract}

Since the enactment of the dual banking system in 1998, Bank Indonesia has a new mandate for regulating both conventional and Islamic banking in Indonesia by enforcing dual monetary policy to attain and maintain the primary objective of Bank Indonesia: price stability. By reconstructing a conceptual model based mainly on Ascarya (2011), this study was designed to empirically examine whether the implementation of dual monetary is effective in ensuring the stability in price level as represented in low inflation as well as stable exchange rate. The method applied in this research was Vector Auto-regression (VAR) Model to capture the response of inflation to the shocks arising from both monetary instruments. The results of this study indicate that 
conventional monetary policy in general-when compared to the Islamic counterpart-may certainly trigger instability of the price level since flawed-cumvulnerable money system (fiat-based money) has fully been implemented, thereby inducing inflation. In addition, the debt system, interbank money market and the fractional reserve banking which are relied heavily on interest system have indeed contributed to the price volatility in Indonesia. In contrast, Islamic monetary policy shocks have proven to be capable of promoting price stability since they could hamper a highly volatile inflation.

Keywords: Price stability, dual monetary system, profit and loss sharing, fractional reserve banking

JEL Classification: E31, E51, E52

\section{Abstrak}

Sejak diberlakukannya sistem perbankan ganda di Indonesia tahun 1998, Bank Indonesia mempunyai mandate baru untuk mengatur perbankan konvensional dan Islam di Indonesia dengan memberlakukan kebijakan moneter ganda untuk mencapai dan menjaga tujuan utama Bank Indonesia: Stabilitas harga. Dengan merekonstruksi model konseptual yang didasarkan pada Ascarya (2011), tulisan ini ditujukan untuk menguji secara empiris apakah penerapan kebijakan moneter ganda efektif untuk memastikan stabilitas harga yang tercermin dari inflasi yang rendah dan nilai tukar yang stabil. Metode yang digunakan dalam tulisan ini adalah Vector Autoregressions (VAR) Model untuk memberikan gambaran atas respon inflasi terhadap guncangan yang berasal dari kedua intrumen moneter tersebut. Hasil dari studi ini menunjukkan bahwa kebijakan moneter konvensional secara umum-ketika dibandingkan dengan kebijakan moneter Islam-membuat ketidakstabilan pada tingkat harga disebabkan penerapan sistem uang 
kertas selama ini yang sangat rentan terhadap krisis, sebagai konsekuensinya akan meningkatkan tingkat harga. lebih lanjut, sistem hutang, pasar uang antar bank dan fractional reserve bankingyang semuanya sangat bergantung pada sistem bunga telah menyebabkan gejolak pada tingkat harga di Indonesia. Sebaliknya, gunjangan dari kebijakan moneter Islam terbukti mampu menodorong kestabilan harga karena semua instumen tersebut mampu menekan gejolak yang terjadi pada inflasi.

Kata Kunci: Stabilitas harga, sistem moneter ganda, profit-and-loss sharing, fractional reserve banking 


\section{Introduction}

Bank Indonesia has a single objective to maintain the stability of the rupiah as reflected in low inflation rate and stable the exchange rate. In achieving stability in the rupiah, Bank Indonesia has three pillars, one of which is formulating and implementing monetary policy. Under the Act No. 3 of 2004, which is an amendment to the Act No. 23 of 1999 a constitutional mandate of Bank Indonesia to maintain the price stability is enshrined and extended. Since then, it has been possible for Bank Indonesia, as stated clearly in the Act, to ensure the stable price level by employing several monetary instruments that entail the instruments based on Sharia principle.

The development of Islamic banking industry in Indonesia has started in the early 1990s, given the official establishment of Bank Muamalat in 1992. The legal protection of Islamic Bank to provide financial services was first under the Act No. 10 of 1998 that has eventually been repealed by the Act No. 21 of 2008. Bank Indonesia in accordancewithsuchlegislation became dual monetary outhority, implementing dual instruments to fulfill its primary objective.
As the new Law has provided the clear legal framework both for monetary authority and the finanacial institutions, there has been a gradually growing Islamic financial institution

functioned under such a dual financial environenment. Adopting dual banking system in which conventional and Islamic banking can function side by side, Indonesia has imposed a dual regulation to govern the banking and financial system owing to a fundamentally different concept between conventional and Islamic monetary instruments. While the main purpose of those instruments is to promote price stability, it is crucial to evaluate how both instruments that have distinct instruments contribute greatly to accomplish a single prupose of Bank Indonesia.

Beside the aforementioned reasons, it is also important to highlight that the central bank has adopted the inflation targeting framework in July 2005, implementing systematically the inflation target to be the benchmark for the inflation rate that needs to be achieved and maintained (Agung et. al, 2016). As such, this can be the underlaying reason why the the effectiveness of dual instruments has to be taken 
into account. In the aftermath of 2008 global financial crisis, January to May 2009 saw sharp decrease in inflation, so it was able to adjust the inflation target. Of monthly inflation, price movements were relatively stable from 2009 until June 2015, except in June 2013 when inflation (yoy) reached $9.0 \%$ well above the target. Rapid fluctuations in the inflation rate may bring about the question that pertains to the effectiveness of monetary policy within the dual monetary system.

The financial crisis that occurs repeatedly in many countries in the world both developed and developing countries always starts with depression, high inflation, asset prices bubbles and then leads to a great depression (Ascarya, 2009a). High inflation is an economicphenomenon thatstill lingers so that has always been a topic of research. Moreover, in the aftermath of the 2008 global financial crisis, many economists began to focus on the problems of credit that has widely belived as a main source of subprime mortgage crisis in the US, therefore in order to develop model proposed by Ascarya (2011), it is necessary first to include conventional credit and Islamic financing in the proposed model this paper seeks to reconstruct. As emphasized recently by Chapra (2017), the primary cause of 2008 financial meltdown was an excessive and imprudent credit extended easily by bank. In fact, such an argument has repeteadly been articulated by several prominent economists such as Mises (1953, 1998 and 2006), Kindleberger (2005), Minsky (1970, 2016), CesaBianchi and Sokol (2017) and Drehmann et al. (2017).

Moreover, this study also attempts to develop the variables responsible for a high inflation. Although the previous study has found some important findings, given the increasingly complex and the development of banking infrastructure and policies, it needs to be further analyzed. Since the study by Ascarya (2011) has not explained yet fractional reserve banking as other factors that play a substantial role in contributing to the price volatility.

\section{Literature Review} IN A DUAL MONETARY
SYSTEM AS IMPLEMENTED IN
INDONESIA, THE MONETARY
AUTHORITY NEEDS TO SYNERGIZE THE
TWO SYSTEMS VERY WELL WITHOUT
LOSING EACH CHARACTERISTIC, IN
ORDER TO ACHIEVE STABILITY IN
THE PRICE LEVEL AND STIMULATE
ECONOMIC GROWTH. THERE HAS
BEEN A GROWING THEORETICAL 
AND EMPIRICAL LITERATURE INVESTIGATING THE PERFORMANCE OF THE DUAL MONETARY SYSTEM ADOPTED IN SEVERAL COUNTRIES. ASCRAYA (2007) ANALYZED AND COMPARED, BOTH THEORETICALLY AND EMPIRICALLY, THE THREE INSTRUMENTS OF THE MONETARY SYSTEM OF CONVENTIONAL AND ISLAMIC, THAT INTEREST RATE VS. A PROFIT-AND-LOSS SHARING (PLS), FIAT MONEY VS. FULL BODIED/ BACKUP MONEY, AND FRACTIONAL VS 100 PERCENT RESERVE-BANKING SYSTEM.

THEORETICALLY,

ALL CONVENTIONAL MONETARY INSTRUMENTS HAVE A GREAT POTENTIAL TO INCREASE VOLATILITY IN PRICES, RESULTING IN HIGH INFLATION COMPARED TO ISLAMIC MONETARY INSTRUMENT. FIRST, THROUGH FIAT MONEY THAT PRINTED BY THE MONETARY AUTHORITY OF A PARTICULAR COUNTRY, WILL PRODUCE MANY BENEFITS OF SEIGNIORAGE. THIS OCCURS BECAUSE THE INTRINSIC VALUE OF PAPER MONEY IS NOT EQUAL TO ITS FACE VALUE; THE INTRINSIC VALUE IS MUCH SMALLER THAN THE NOMINAL VALUE STATED IN MONEY. UNLIKE THE MONEY IN ISLAM REQUIRES THAT MONEY HAS INTRINSIC VALUE EQUAL TO ITS NOMINAL VALUE, SUCH AS GOLD AND SILVER, SO THAT WITHIN THE FRAMEWORK OF ISLAMIC MONEY THERE IS NO AUTHORITY WHICH EARNS HUGE PROFITS BY PRINTING MONEY.

Not to mention the fractional reserve banking system, which the banking system is able to create moneydemand deposits, for example. In this context, money is created by banks when issuing bank loan, the more loan issued through this system the more money will automatically be created. Hence, such a system can threaten severely the price stability. In contrast, in the Islamic system is through 100 percent reserve banking, banks can not create money.

Lastly, the interest rate instrument and PLS, Ascraya (2007) describe theoretically and empirically. Interest rate well, theoretically and empirically, negatively associated with investments, meaning that when interest rates rise and investment will fall, it will also have a negative impact on economic growth. Investment and economic growth are positively related to each other: a significant increase in investment will encourage economic growth. Unfortunately, the economic growth will be disturbed by the presence of a negative relationship between investment and the interest rate. While the PLS system, PLS and investment relations are positive. That said, when the PLS rises, the investment will go up hence a high level of investment will also lead the economy to grow. 


\section{Ascarya}

formulate ideal

(2009b) between conventional and Islamic monetary policy that will achieve the stability of price level and economic growth. The conventional system, according to its instruments characteristics, such as interest rates, fiat money, and fractional reserve banking system allowing speculation to get the maximum benefit. Worse, the benefits were only enjoyed by a minority group. So the money that should be spinning for real sector instead accumulates in the monetary sector. Thus, economic bubbles become unavoidable. While in the Islamic system through PLS, Zakah system and a ban on speculation in Islam will improve the investment climate is healthy and based on sector willingly so will minimize bubbles and economic growth can be realized.

In a dual monetary system, both systems explained above with their respective characteristics must work together. Ascarya stressed that in order to create the desired synergy, both systems must work side by side in accordance with their respective paradigm do not mix and merge with each other. An instrument that can unite these two systems is that the profit-and-loss sharing (PLS). In terms of monetary policy, the monetary authorities need to leave the monetary policy of passive (creating/ adding money to the economy) with an active monetary policy that emphasizes to accelerate $V$ (velocity of money in the economy) by issuing sukuk based on the PLS system.

In the context of Indonesiathathasimplemented a dual monetary system, Ascarya (2010) suggests that conventional economics contains the root causes of the systemic problems of the crisis. Several root causes of high inflation are riba, which is not limited in the form of interest rate but on the creation of a system of money and banking system which is rested greatly on fractional reserve banking.

$$
\text { Ascarya }
$$

attempted to examine the determinants of inflation under a dual monetary system in Indonesia from two perspectives; Conventional and Islam then formulate systematic steps to reduce and maintain inflation. This study applied Vector Auto Regression (VAR) and Vector Error Correction Model (VECM). By using the Impulse Response Function (IRF) this study found that the shocks of variable conventional and Islamic responded Distinct vary by inflation. Interest rates have a large and negative impact on 
inflation (increasing inflation) permanently, compared with PLS whose influence is much smaller. The same result is also shown from the negative effects of multiple currency systems and permanent outweigh GOLD single currency against inflation. Moreover, Saharuddin and Rama (2016) found that gold has stiil triggered the inflation if implemented. While the biggest contributor to inflation in the dual monetary system of Indonesia is interest rate with $54.7 \%$ share. This study has not been able to prove empirically that credit creation of fractional reserve banking system is one of the main causes of inflation. Study conducted

by by Herianingrum and Syapriatama (2016) has entailed both conventional and Islamic loan in the model, yet the fractional reserve banking as stated by previous studies has yet to be addressed. In contrast, Yuliadi et al. (2017) seemed to fill that gaps by incorporating fractional reserve system into their model, however the main important cause of crisis which is credit was not included.

\section{Methodology and Data 3.1 Data}

In order to fully grasp the condition of monetary system within dual system, this study applies the empirical methodology to examine the dynamic relationship between instruments, namely Vector Auto Regression (VAR). Therefore, the montly basis data of financial variables from both conventional and Islamic are required by such a quantitative method. The data of this study were obtained from various resources, encompassing every institution from Bank Indonesia (SEKI-BI), Financial Services Authority (SBI and SPS) to Biro Pusat Statistik (BPS) and covered the period from January 2009 to June 2015. The period of 2009 was chosen to be the starting point of this paper since it was the period after the Act No. 102008 about Islamic Banking in Indonesia being enacted.

\subsection{Vector Auto Regressive (VAR) Model}

Analyzing the response of price stability as represented by the inflation to the shocks emanating from conventional and Islamic monetary instruments, this study uses the vector auto regressive (VAR). Meanwhile, if the variables included in the model have cointegration as can be tested by Johansen cointegration, this means that the long-term analsysis can be conducted 
in Vector Error Correction Model. Hence, VECM is also called as VAR that is designed for non stationary series or stationary at first difference level which has long-term cointegration (Ascarya, 2009b). Otherwise, if there is no lon term cointegration between variabeles, this study employs the first difference of VAR model. The general model of VECM can be written as equation (3.1)

$\Delta x_{t}=\mu_{t}+\prod x_{t-1}+\sum_{i=1}^{k-1} \Gamma_{i} \Delta x_{t-i}+\varepsilon_{t}$

Where:

$x_{k}$ is $k$ all variables thretaed as endogenous, flexible according to the model;

$\varepsilon_{k}$ is disturbance or error term with zero means and constant variancecovariance.

The model used in this study followed Ascarya (2011), where variables will be divided into conventional monetary policy and Islamic monetary policy; then will be tested how both monetary policies can induce or reduce price level volatility. Moreover, price stability can be defined according to the stability of inflation by assessing the response of costumer price index from both monetary policy shocks. Therefore, the research models under dual monetary policy system are as follows:

Conventional monetary policy model:

$$
x_{k}=\text { [Inflation, } \operatorname{lnFM} \text {, }
$$
$\operatorname{lnFRB}$, INT, $\operatorname{lnEXC}$, rPUAB, $\ln L O A N]$

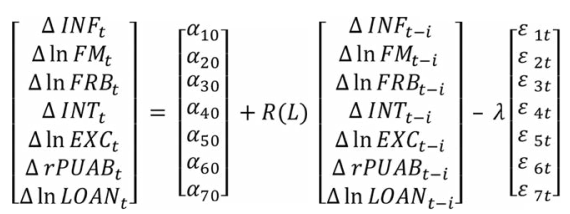

Islamic monetary policy model: $x_{k}=$ [Inflation, GOLD, PLS, lnIM, rPUAS, lnFINC]

$\left[\begin{array}{c}\Delta I N F_{t} \\ \Delta G O L D_{t} \\ \Delta P L S_{t} \\ \Delta \ln I M_{t} \\ \Delta r P U A S_{t} \\ \Delta \ln \text { FINC }_{t}\end{array}\right]=\left[\begin{array}{l}\beta_{10} \\ \beta_{20} \\ \beta_{30} \\ \beta_{40} \\ \beta_{50} \\ \beta_{60}\end{array}\right]+R(L)\left[\begin{array}{c}\Delta I N F_{t-i} \\ \Delta G O L D_{t-i} \\ \Delta P L S_{t-i} \\ \Delta I M_{t-i} \\ \Delta r P U A S_{t-i} \\ \Delta \ln F I N C_{t-i}\end{array}\right]-\lambda\left[\begin{array}{l}\mu_{1 t} \\ \mu_{2 t} \\ \mu_{3 t} \\ \mu_{4 t} \\ \mu_{5 t} \\ \mu_{6 t}\end{array}\right]$

Where $\mathrm{R}$ is matrix polynomial parameter estimator which consists of $7 \times 7$ in the conventional and $6 \times 6$ in Islamic model respectively; $\mathrm{L}$ is the lag length operator; $\Delta$ is the difference operator; denotes the level of adjustment from short-term to long-term equilibrium if the VAR model is co-inetgrated.

Where:

- INF: the monthly CPI (consumer price index) inflation obtained from table "Indeks Harga Konsumen 
dan Inflasi Bulanan

Indonesia", BPS.

- INT: the rate of one-month conventional time deposits, obtained from table I.28 "Suku bunga simpanan berjangka rupiah menurut kelompok bank": Bank Umum 1/3/6/12/24 bulan, SEKI-BI.

- PLS: the rate of one-month Islamic time deposits (deposito iB), obtained from table 36 "Ekuivalen Tingkat Imbalan bagi hasil/fee/ bonus - Bank Umum Syariah dan Unit Usaha Syariah": Time Deposits - 1 month, SPS-BI.

- FM: money creation originally issued by the central bank or money in circulation (M2), obtained from table I.2 "Neraca analitis otoritas moneter": Uang Kartal yang diedarkan, SEKI-BI.

- FRB: credit creation or fractional reserve banking, is the difference between broad money M2 and M0 monthly. Broad money M2, obtained from table I.1 "Uang Beredar dan Faktor-Faktor yang Mempengaruhinya": M2, SEKI-BI.

- IM: Just money supply or money needed in the economy in Islamic perspective, which is an equilibrium intrinsic M0 proximate by the monthly
M1 and GDP data obtained from SEKI-BI and BPS.

- LOAN: the outstanding amount (total loan) of conventional banks gained from Indonesian Banking Statistics (SPI)-BI.

- FINC: the outstanding amount (total financing) of Islamic banks acquired from Islamic Banking Statistics (SPS)-BI.

- EXC: Multiple currency systems or exchange rate is the exchange rate of Rupiah against the US Dollar gained from SEKI-BI.

- GOLD: Single global currency or gold price, is international gold price index obtained from "Indeks Harga Energi", SEKI-BI.

\section{Result and Analysis \\ 4.1 Preliminary Test}

Before discussing the results of VAR model, it is compulsory to meet several processes including unit root test, stability test, and cointegration tets to examine whether the model in this paper has cointegration in the long term. First, unit root test results show that most variables are not stationary in level, except two variables that is inflation and growth but all variables are stationary in first difference (see Appendix a). Second, in terms of stability of 
the model, the results suggest that both models (conventional and Islamic) are stable as swhown in the figure below, price level to shocks every monetary policy; both in terms of conventional and Islamic. The response rate is seen form


Figure 4.1 Conventional Model (right) and Islamic Model (left)

Third, optimum lag the Impulse Response; when test for both conventional and the response rises (upward Islamic model are 1 (one) as and positive), then the price the results of selection order level in this case has increased, criteria demonstrate the lag 1 (one) (see Appendix $\mathrm{b}$ and d). Fourth, to assess the cointegration, this study employs Johansen Cointegration test. The result demonstrates that there is no cointegration in both models since the trace statistics exceeds the critical value (see Appendix c and e). From the cointegration result, it can be concluded that this paper applies VAR model instead of VECM.

\subsection{VAR of Conventional Monetary Model}

In this section will explain the response of the meaning that any changes or shocks that occur in monetary policy resulted in price volatility rises. Conversely, when the response rate of price decreases (toward negative) it means a change in the monetary policy side is able to reduce the price level. Furthermore, in this section it will also be shown how to price stability occurs, when there is a mix between those two policies to maintain price levels, so it can be illustrated by how comprehensively price stability has been maintained in the dual monetary system in Indonesia. In addition, the 
contribution of each monetary policy-will either raise or lower the price level-will be explained also by the results of the variance decomposition, so it would seem any policies that contribute the most dominant to stabilize the price level in the dual monetary system.
From the model (1) and (3), it is apparent that the credit (Loan) of conventional has a signifantly positive impact on the inflation, this means that the more the credit is extended to the borrowers the easier it is to trigger the high inflation. Moreover, Table 4.1 VAR of Conventional Model

\begin{tabular}{|c|c|c|c|c|c|c|c|}
\hline $\begin{array}{l}\text { Dep. var: } \\
\Delta \text { inf }\end{array}$ & (1) & (2) & (3) & (4) & (5) & (6) & (7) \\
\hline$\Delta \inf _{t-1}$ & $\begin{array}{l}-0.478^{* * *} \\
(-4.93)\end{array}$ & $\begin{array}{l}-0.478^{* * *} \\
(-5.02)\end{array}$ & $\begin{array}{l}-0.479^{* * *} \\
(-4.95)\end{array}$ & $\begin{array}{l}-0.522^{* * *} \\
(-5.21)\end{array}$ & $\begin{array}{l}-0.487^{* * *} \\
(-5.08)\end{array}$ & $\begin{array}{l}-0.477^{* * *} \\
(-4.85)\end{array}$ & $\begin{array}{l}-0.475^{\star * *} \\
(-4.99)\end{array}$ \\
\hline$\Delta \operatorname{lnLOAN}{ }_{t-1}$ & $\begin{array}{l}6.490^{* *} \\
(2.22)\end{array}$ & & $\begin{array}{l}5.882^{*} \\
(1.83)\end{array}$ & & & & \\
\hline$\Delta \mathrm{fm}_{\mathrm{t}-1}$ & & $\begin{array}{l}-0.713 \\
(-0.40)\end{array}$ & & & $\begin{array}{l}1.577 \\
(1.31)\end{array}$ & $\begin{array}{l}2.038^{*} \\
(1.68)\end{array}$ & \\
\hline$\Delta \mathrm{frb}_{\mathrm{t}-1}$ & & $\begin{array}{l}7.159^{*} \\
(1.96)\end{array}$ & & & & & $\begin{array}{l}6.466^{* * *} \\
(2.79)\end{array}$ \\
\hline$\Delta$ int $_{t-1}$ & & $\begin{array}{l}0.0688 \\
(0.50)\end{array}$ & $\begin{array}{l}0.0659 \\
(0.45)\end{array}$ & & & & \\
\hline$\Delta \mathrm{exc}_{\mathrm{t}-1}$ & & & & $\begin{array}{l}2.100 \\
(1.45)\end{array}$ & & & \\
\hline$\Delta$ puab $_{\mathrm{t}-1}$ & & & & & $\begin{array}{l}0.218^{* *} \\
(2.08)\end{array}$ & & \\
\hline _cons & $\begin{array}{l}-0.0903^{*} \\
(-1.69)\end{array}$ & $\begin{array}{l}-0.0671 \\
(-1.49)\end{array}$ & $\begin{array}{l}-0.0796 \\
(-1.36)\end{array}$ & $\begin{array}{l}-0.00316 \\
(-0.09)\end{array}$ & $\begin{array}{l}-0.00650 \\
(-0.18)\end{array}$ & $\begin{array}{l}-0.0206 \\
(-0.56)\end{array}$ & $\begin{array}{l}-0.0694^{*} \\
(-1.66)\end{array}$ \\
\hline $\mathrm{N}$ & 76 & 76 & 76 & 76 & 76 & 76 & 76 \\
\hline$R^{2}$ & 0.290 & 0.319 & 0.292 & 0.264 & 0.310 & 0.271 & 0.314 \\
\hline
\end{tabular}

$t$ statistics in parentheses

${ }^{*} \mathrm{p}<.1,{ }^{* *} \mathrm{p}<.05,{ }^{* * *} \mathrm{p}<.01$ 
the fiat money along (model 6) with fractional reserve banking system (model 2 and 7) has a positive relationship with the price level: if FM and FRB increase 1 per cent, due to a positive coefficient, both will bring about the rise in inflation rate 2.03 and 6.46, respectively. It can be argued that fiat money and fractional reserve system has been detrimental for price stability. The other three variables, namely interest rate, puab rate and exchang rate have a positive relation to inflation, however only puab rate that can significantly contribute to the price volatility.

The previous results are in line with the Impulse ResponseFunction(IRF)results of Inflation for conventional policy model as can be seen in figure 4.2. IRF results show that all conventional variables induce inflation especially: fiat money ' $\mathrm{FM}^{\prime}$, followed by total credit outstanding 'LOAN', fractional reserve banking 'FRB', interest rate 'INT', interbank money market rate ' $P P U A B$ ' and the last is exchange rate 'EXC'.

To see how much the contribution of both the policy in maintaining price stability, FEVD is applied. Forecast Error Variance Decomposition (FEVD) results for conventional policy (see figure 4.3) show that fractional reserve banking 'FRB' with $7.5 \%$ is the main contributor of high volatility in price level, followed by interbank call money market rate ' $\mathrm{PPUAB}$ ' with $3.8 \%$, total loan 'LOAN' with 3\% share, exchange rate 'EXC' with 1\% share, interest rate 'INT' $(0.03 \%)$, and the last is fiat money ' $\mathrm{FM}^{\prime}$ ' which gives the highest share $(0.01 \%)$ to induce inflation.



Figure 4.2 Responses of CPI Inflation to Conventinal Monetary Policy Shocks 


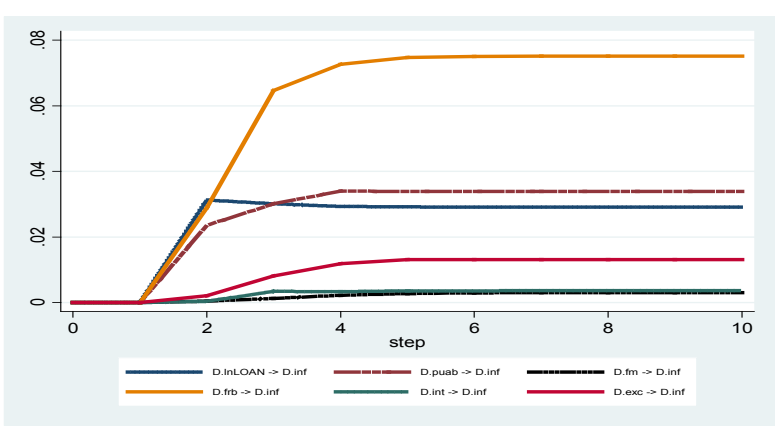

Figure 4.3 FEVD Results of Conventional monetary instruments to Price Level

Shocks that occur in conventional monetary instruments, especially in a system based on fiat money and fractional reserve banking, make the price level to rise long term. It can not be avoided because the system of paper money is inflationary, so do not be surprised if fiat money 'FM' as a means of transaction has the greatest role in raising significantly the level of the price. In any creation, banknotes These findings confirm the historical volatility after the collapse of the Bretton Woods Agreements in 1972; characterized by high frequency inflation and a series of crises which are becoming more frequent. One thing that can not be avoided, that the seigniorage profits are always obtained through printing fiat money, this is what makes the money supply in the economy increases and rising inflation becomes unavoidable.
The total outstanding credit, which in conventional systems, can becreated through the mechanism of fractional reserve banking system. Debt or leveraging originally a sign of economic expansion, but when the debt has been accumulated will lead to asset price bubbles. In this case, Meera (2002) explains that the support system of fractional reserve banking 'FRB' are applied in banking is the interest rate; where the interest rate 'INT' was instrumental in the formation and additional money through debt (new loans) in the banking system calculation. The banking system that is run by fractional reserve banking able to create money and add new loans but unable to ensure well-being.

Total loans issued by banks in the long term have very large impact on the rise of inflation, it is in line with the system used to create a 
whole debt, that fractional reserve banking. Although in the short term, the loan does not affect the stability of prices but in the long term, the accumulated loan capable of being a threat to price stability. These empirical results prove explanation Shirakawa (2015) states that the accumulated debt that could be the root of asset price bubbles, because the debt could be an indicator of macroeconomic stability.

Interbank call money market rate (rPUAB) which is the benchmark lending rate between conventional banks also causes price volatility. Exchange rate (EXC) in the early period were able to lower the price level, because as a means of monetary transmission to dampen inflation, exchange rate is effective in the short term, but after a period of five shocks that occur in the exchange rate responded negatively by the price level, in other words improving instability in CPI.

Furthermore, Ascarya (2007; 2009; and 2010) stressed that the monetary system based on fiat money is likely to be instability and even crises. With fiat money system, it would be very easy to get the benefits of seigniorage for the cost of printing money is lower than the value of paper money itself so high and unstable inflation becomes inevitable. And not surprisingly, the FRB also give the same effect, because According to Meera (2002) that the interest rate is actually an important factor in the creation of money through fractional reserve banking system, and the money created through the FRB would be circulated into new debt 'LOAN'.

The banking system that implements fractional reserve banking system is able to automatically create money through issuing new debt, so that in the long term was 'FRB' pose a threat to price stability. These results successfully demonstrated empirically that the FRB are the main factors that cause inflation, and these results also complement the findings by Ascarya (2011).

\subsection{VAR of Islamic Monetary Model}

The table 4.2 below shows the estimation results of several monetary instruments based on sharia principle. All Islamic variables are capable of reducing the price volatility in Indonesia since they have a negative coefficient with the exception of gold which has a positive coefficient. 
Table 4.2 VAR of Islamic Model

\begin{tabular}{|c|c|c|c|c|c|}
\hline $\begin{array}{l}\text { Dep. var: } \\
\Delta \inf \end{array}$ & (1) & (2) & (3) & (4) & (5) \\
\hline$\Delta \inf _{t-1}$ & $\begin{array}{l}0.388^{* * *} \\
(3.67)\end{array}$ & $\begin{array}{l}0.388^{* * *} \\
(3.67)\end{array}$ & $\begin{array}{l}0.399 * * * \\
(3.72)\end{array}$ & $\begin{array}{l}0.389 * * * \\
(3.69)\end{array}$ & $\begin{array}{l}0.390 * * * \\
(3.68)\end{array}$ \\
\hline$\Delta \operatorname{lnFINC}{ }_{t-1}$ & $\begin{array}{l}-0.871 \\
(-0.18)\end{array}$ & & & & $\begin{array}{l}-0.736 \\
(-0.15)\end{array}$ \\
\hline$\Delta$ gold $_{\mathrm{t}-1}$ & & $\begin{array}{l}0.000767 \\
(0.23)\end{array}$ & $\begin{array}{l}0.00109 \\
(0.31)\end{array}$ & & \\
\hline$\Delta \mathrm{im}_{\mathrm{t}-1}$ & & & $\begin{array}{l}-1.026 \\
(-0.56)\end{array}$ & & \\
\hline$\Delta \mathrm{pls}_{\mathrm{t}-1}$ & & & & $\begin{array}{l}-0.0554 \\
(-0.45)\end{array}$ & $\begin{array}{l}-0.0538 \\
(-0.43)\end{array}$ \\
\hline$\Delta$ puas $_{\mathrm{t}-1}$ & & & & $\begin{array}{l}-0.0158 \\
(-0.11)\end{array}$ & \\
\hline _cons & $\begin{array}{l}0.0119 \\
(0.09)\end{array}$ & $\begin{array}{l}-0.00636 \\
(-0.08)\end{array}$ & $\begin{array}{l}0.00814 \\
(0.10)\end{array}$ & $\begin{array}{l}-0.00822 \\
(-0.11)\end{array}$ & $\begin{array}{l}0.00876 \\
(0.07)\end{array}$ \\
\hline $\mathrm{N}$ & 76 & 76 & 76 & 76 & 76 \\
\hline$R^{2}$ & 0.150 & 0.150 & 0.154 & 0.152 & 0.152 \\
\hline
\end{tabular}

$t$ statistics in parentheses

${ }^{*} \mathrm{p}<.1,{ }^{* *} \mathrm{p}<.05,{ }^{* * *} \mathrm{p}<.01$

Islamic financing which is distributed the volatility is based on real sector activity of inflation can effectively be (model 1 and 5) can negatively dampened. It can be argued affect the inflation but not that such a condition may significant and hence when the occur because of the share volume of Islamic financing of Islamic banking which is 
relatively small compared to conventional counterpart, so that it can not significantly impact the inflation. Islamic money along with profit and loss sharing has also a negative effect on inflation while the impact is not significant.

Almost all Islamic monetary instruments (see figure 4.4) such as profit and loss sharing 'PLS', Islamic interbank call money market 'rPUAS', Total financing 'FINC', base money 'IM' can reduce inflation or stabilize price level however gold 'GOLD' which is believed to be the main factor of promoting the price stability induce inflation.

The Impulse Response Function (IRF) supports the estimation results. Shocks that occur from Islamic variables are responded positively by inflation thereby they are able to stabilize the price level. In this case, IRF indicates that Islamic money (IM) gives the most effect on price volatility reduction because in Islamic monetary policy, financing should be based on the real sector which is able to increase investment and boost the economy. Profit-and-loss sharing 'PLS' has an impact on reducing the price volatility, because the PLS system is a growth-oriented real sector, unlike the conventional interest rate. Chapra (2017) proposed the risk-sharing principle to be adopted in the mainstream system since it can safeguard the whole financial system, promoting a prudent debt. In addition, Ascarya (2009b) stressed that profitand-loss sharing which should be the principle also in Islamic financing is perfectly fair system wherein both investors and entrepreneurs can share the profit gained from the business activities as well as the loss incurred in the future. As a result, the exploited party can initially be avoided.

In addition, policy sharia interbank money market rate (rPUAS) also plays a role in dampening inflation, the same as former variable, since rPUAS is based on profit sharing rate in Islamic banking. Furthermore, the single currency 'GOLD' seems to be resulting in instability of the price level. This finding is in aggrement with study by Ascraya (2011) which showed that gold still has the potential to increase the inflation rate even though its contribution is smaller than the application of the multiple currencies ' $E X C^{\prime}$.

The results for Islamic model (see figure 4.5) show Islamic money (IM) has a highest share in curbing the inflation with $0.025 \%$ share, followed by profit-and-loss 
sharing 'PLS' with the share $(0.024 \%)$ to reduce inflation, total financing 'FINC' with $(0.04 \%)$ share, and interbank syariah call money market (rPUAS) with $0.01 \%$ share, while GOLD (0.14\%) appears to be the contributor of inflation. This is consistent with the findings of Ascraya (2009a \& 2011) which states that in order to prevent price volatility, PLS could be applied alternative (and optimized) to dampen inflation.
Islamic policies in the shortterm havea fairly effective role in bringing about stability in prices. This suggests that to achieve stability in the price level or inflation in accordance with the target of Bank Indonesia, the two policies are mutually reinforcing. Through this model, we can conclude that Islamic monetary policy play an effective role in ensuring price stability while conventional monetary policy to effectively control the price

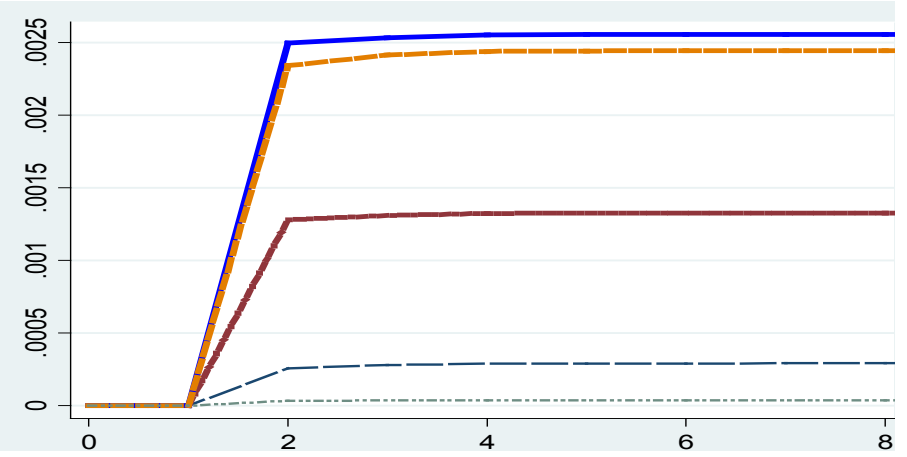

Figure 4.4 Responses of CPI Inflation to Islamic Monetary Policy Shocks
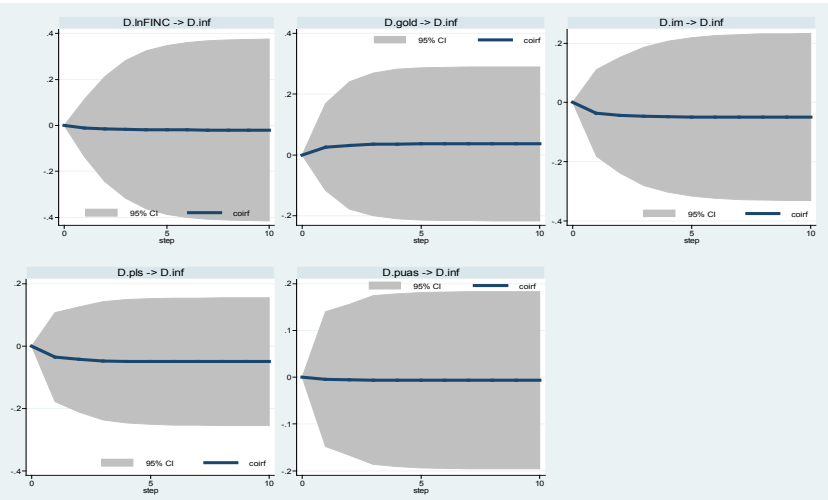

Figure 4.5 FEVD Results of Islamic monetary policy to Price Level 
level in the initial period only; in the long run it causes price volatility.

With the results as described above, in the context of the application of the dual monetary system in Indonesia, not all conventional monetary policy is able to ensure and maintain price stability, as one of the objectives of the central bank. However, Islamic monetary policy also has a good performance in order to realize these objectives. Although the market share of Shariah banking is relatively lagging behind from conventional banking, but the results already provide empirical evidence for the contribution of the Islamic policy.

\section{v. Conclusion}

From the results of VAR for conventional monetary model, it is apparent that all variables are inducing the inflation in Indonesia in particular credit. As the previous studies seem to exclude credit in the model, this study is able to grasp the information about the detrimental effect of credit on increasing the likelihood of high inflation that may certainly lead to a great crisis. Moreover, since this paper seeks to include fractional reserve banking in the model, it can be concluded that it is capable of filling the gap of the study undertaken by Ascarya (2011), and other previous researches done by Herianingrum and Syapriatama (2016) and Yuliadi et al. (2016). The result indicates that such a fractional reserve system tends to be the key contributor of price volatility in dual banking system adopted by Indonesia. While the interest rate does not impact the inflation, the interbank money market rate (rPUAB) which is rested on interest system appers to be a major threat to price stability.

In contrast, Islamic monetary instruments are proven to be effective in curbing inflation as shown in the estimation results as well as IRF. It is clearly seen that all Islamic instruments has a negative impact on inflation, hence the full implementation of this policy will result in a stable price level. Yet, gold which is widely believed to stable becomes the only Islamic instrument that can possibly trigger the inflation.

By looking at the results of the two models of this study, it can be concluded that the monetary policy of Islam in the dual monetary policy can contribute to reducing instability in the price level in Indonesia. 


\section{References}

Achsani, Noer Azam, Oliver Holtemoller, and Hizir Sofyan. (2005). "Econometric and Fuzzy Modeling of Indonesian Money Demand." In Statistical Tools for Finance and Insurance. Pavel Cizek, Wolfgang Hardle, and Rafal Weron (eds.). Berlin Heidelberg, Germany: SpringerVerlag. pp. 249-270.

Agung, Juda, Solikin M Juhro, Harmanta and Tarsidin. (2016). Managing Monetary and Financial Stability in a Dynamic Global Environment: Bank Indonesia's Policy Perspectives. BIS Papers No 88 (October).

Alamsyah, Halim, J. Adamanti, Diana Yumanita, and R. I. Astuti. (2014). Siklus Keuangan Indonesia. Bank Indonesia Working Paper (No. WP/8/2014), December.

Ascarya. (2007). Optimum Monetary Policy under Dual Financial/Banking System. Paper presented at $2^{\text {nd }}$ Islamic Conference (iECONS2007). Faculty of Economics and $\mathrm{Mu}^{\prime}$ amalat, Islamic Science University of Malaysia.

Ascarya. (2009a). Lessons Learned from Repeated Financial Crisis: An Islamic Perspective. Bulletin of Monetary Economics and Banking 12(1): 27 - 69.

Ascarya. (2009b). Toward Optimum Synergy of Monetary Policy in Dual Financial/Banking System. Journal of Indonesian Economiy and Business 24(1): $33-48$.

Ascarya. (2010). The Future of Dual Monetary Policy in the Light of Global Financial Crises: The Case of Indonesia. Paper selected $3^{r d}$ KLIFF Essay Competition on Islamic Finance 2010. Kuala Lumpur, Malaysia, August 3-4.

Ascarya. (2011). How to Eradicate Inflation under Dual Monetary System: The Case of Indonesia. Paper presented at $8^{\text {th }}$ International Conference on Tawhidi Methodology Applied to Microenterprise Development. IEF-TRISAKTI, Jakarta, Indonesia, January 7-8, 2011. 
Ascarya. (2013). Developing Monetary Policy under Dual Financial System in Indonesia. Presentation delivered in Public Lecture on Islamic Financial System. Universitas Muhammadiyah Yogyakarta, Yogyakarta, September 21, 2013.

Cesa-Bianchi, Ambrogio and Sokol, Andrej. (2017). Financial Shocks, Credit Spreads and International Credit Channel. StaffWorking Paper No. 693. Bank of England (November).

Chapra, M. Umer. (2017). The Looming International Financial Crisis: Can the Introduction of Risk Sharing in the Financial System as Required by Islamic Finance Play a Positive Role in Reducing its Severity?. Islamic Economic Studies 25(2): 1-13.

De-Ramon, Sebastian and Straughan, M. (2017). The Economic Cost od Capital: a VECM Approach for estimating and Testing the Banking Sector's Response to changes in Capital Ratios. Staff Working Paper No. 663. Bank of England. (June).

Drehmann, Mathias, Juselius, M and Korinek, A. (2017). Accounting for Debt Service: the Painful Legacy of Credit Booms. BIS Working Paper No. 645. Bank for International Settlements.

Enders, Walter. (2010). Applied Econometric Time Series. Third Edition. Hoboken: John Wiley \& Sons, Inc.

Hayek. F. A. (1976). Denationalisation of Money. Westminster, London: The Institute of Economic Affairs.

Hayek. F. A. (2008). Prices and Production and other Works: F.A. Hayek on Money, The Business Cycle, and Gold Standard. Edited by Joseph T. Salerno. Auburn, Alabama: Ludwig von Mises Institute.

Herianingrum, S and Syapriatama, I. (2016). Dual Monetary System and Macroeconomic Performance in Indonesia. Al-Iqthishad: Journal of Islamic Economics 8(1): 65-80. 
Kindleberger, Charles P. and R. Z. Aliber. (2005). Manias, Panics, and Crashes: A History of Financial Crises. Fifth Edition. New Jersey: John Wiley \& Sons, Inc.

Meera. A. K. Mydin. (2002). The Islamic Gold Dinar. Selangor, Malaysia: Pelanduk Publications (M) Sdn Bhd.

Meera. A. K. Mydin. (2004). The Theft of Nations: Returning to Gold. Selangor, Malaysia: Pelanduk Publications (M) Sdn Bhd.

Minsky, Hyman. P. (1970). Financial Instability Revisited: The Economics of Disaster. Paper prepared for the Steering Committee for the Fundamental Discount Mechanism Appointed by the Board of Governors of the Federal Reserve System. 1-64.

Minsky, Hyman. P. (2016). Can "It" Happen Again?: Essays on Instability and Finance. With a new foreword by Jan Toporowski. London and New York: Routledge Classics. Mises. Ludwig Von. (1953). The Theory of Money and Credit. New Haven: Yale University Press.

Mises. Ludwig Von. (1998). Interventionalism: An Economic Analysis. Edited by Bettina Bien Greaves. New York: The Foundation for Economic Education, Inc.

Mises. Ludwig Von. (2006). The Causes of The Economic Crisis and other Essays Before and After the Great Depression. Auburn, Alabama: Ludwig von Mises Institute.

Saharuddin, D. and Rama, Ali. (2017). Currency System and Its Impact on Economic Stability. Al-Iqthishad: Journal of Islamic Economics 9(2): 289-310.

Shrestha, Min B. dan Khorshed Chowdhury. (2005). ARDL Modelling A pproach to Testing theFinancial Liberalisation Hypothesis. Working Paper 05-15. Department of Economics, University of Wollongong.

Wiranatakusuma, D. B. and Salina H. Kassim. (2013). Evaluating Monetary Transmission Mechanism in Indonesia 
through Exchange Rate Channel. Jurnal Ekonomi dan Studi Pembangunan 14(2): 91-100.

Yuliadi, I., Wiranatakusuma, D. B and Syahputra, A. S. (2016). Dynamics of Inflation Determinants under Dual Monetary Systems: Empirical Evidences from Indonesia and Malaysia. Jurnal Ekonomi dan Bisnis Islam 2(2): 149166.

a. Unit Root test

\section{Appendix}

\begin{tabular}{|l|l|l|l|l|}
\hline \multirow{2}{*}{ Variable } & \multicolumn{2}{|l|}{ ADF Value } & \multicolumn{2}{l|}{ MacKinnon Critical Value (5\%) } \\
\cline { 2 - 5 } & Level & $1^{\text {st }}$ Difference & Level & $1^{\text {st }}$ Difference \\
\hline CPI Inf & -3.091589 & -5.967617 & -2.900137 & -2.900670 \\
\hline IM & -2.139282 & -7.189076 & -2.901217 & -2.901217 \\
\hline GOLD & -0.413825 & -7.995538 & -2.899619 & -2.900137 \\
\hline PLS & -2.805238 & -11.76616 & -2.899619 & -2.900137 \\
\hline INT & -2.089824 & -3.662435 & -2.900670 & -2.900670 \\
\hline FM & -0.819366 & -8.400545 & -2.899619 & -2.900670 \\
\hline LOAN & -0.627279 & -4.201535 & -2.899619 & -3.480463 \\
\hline FINC & -2.136680 & -3.614344 & -2.900670 & -3.470851 \\
\hline FRB & -0.287591 & -8.874091 & -2.900670 & -2.900670 \\
\hline EXCH & 0.319318 & -7.524795 & -2.899619 & -2.900137 \\
\hline PUAB & -3.081866 & -8.237052 & -2.899619 & -2.900137 \\
\hline PUAS & -3.598283 & -11.36603 & -2.899619 & -2.900137 \\
\hline
\end{tabular}

b. Selelction-order Criteria (for Conventional model)

\begin{tabular}{|r|rlllllll|}
\hline lag & LL & LR & df & p & FPE & AIC & HQIC & SBIC \\
\hline 0 & 302.31 & & & & $8.1 e-13$ & -7.98135 & -7.89441 & -7.7634 \\
1 & 917.161 & 1229.7 & 49 & 0.000 & $1.9 e-19 *$ & $-23.2746 *$ & $-22.5791 *$ & $-21.531 *$ \\
2 & 956.357 & $78.393^{*}$ & 49 & 0.005 & $2.5 e-19$ & -23.0097 & -21.7055 & -19.7404 \\
3 & 982.692 & 52.67 & 49 & 0.334 & $5.0 e-19$ & -22.3971 & -20.4843 & -17.6021 \\
4 & 1007.1 & 48.82 & 49 & 0.480 & $1.2 e-18$ & -21.7325 & -19.2111 & -15.4119 \\
\hline
\end{tabular}

Endogenous: InIHK InLOAN puab fm frb indep exc 


\section{c. Johansen Cointegration Test (for Conventional model)}

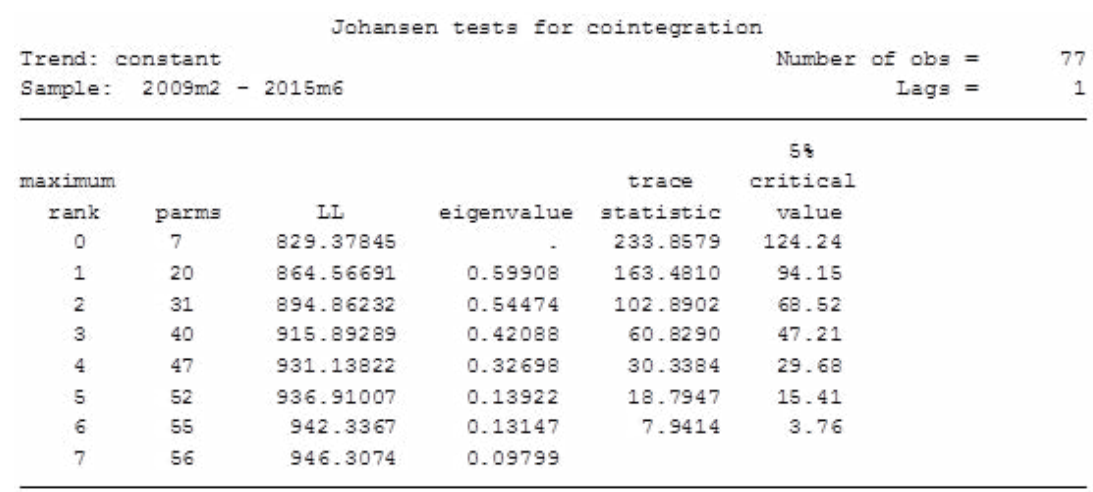

\section{d. Selelction-order Criteria (for Islamic model)}

$\begin{aligned} & \text { Selection-order criteria } \\
& \text { Sample: } 2009 \mathrm{~m} 5 \\
& -2015 \mathrm{~m} 6\end{aligned}$
\begin{tabular}{|r|ccccccccc|}
\hline lag & LI & LR & df & p & FPE & AIC & HQIC & SBIC \\
\hline 0 & -669.641 & & & & 3.43262 & 18.2606 & 18.3351 & 18.4474 \\
1 & -130.512 & 1078.3 & 36 & 0.000 & $4.3 e-06^{*}$ & $4.66247 *$ & $5.18414^{*}$ & $5.97019^{*}$ \\
2 & -102.096 & 56.831 & 36 & 0.015 & $5.4 e-06$ & 4.86746 & 5.83626 & 7.29606 \\
3 & -74.9123 & $54.367 *$ & 36 & 0.025 & $7.1 e-06$ & 5.10574 & 6.52168 & 8.65524 \\
4 & -52.7129 & 44.399 & 36 & 0.159 & .000011 & 5.47873 & 7.34181 & 10.1491 \\
\hline
\end{tabular}

Endogenous: inf lnFINC gold mo pls puas

Exogenous: _cons

e. Johansen Cointegration Test (for Islamic model)

\begin{tabular}{|c|c|c|c|c|c|c|}
\hline $\begin{array}{l}\text { Ixend: } 0 \\
\text { semple: }\end{array}$ & $\begin{array}{l}\text { natent } \\
2009 m 4\end{array}$ & $2015 \mathrm{~m} \theta$ & & & $\begin{array}{r}\text { Numbe }=0 \text { obs - } \\
\text { Lags - }\end{array}$ & $\begin{array}{r}7 \pi \\
3\end{array}$ \\
\hline & & & & & 58 & \\
\hline$m 2 x \leq m u m$ & & & & $t=200$ & $c=1 t \leq c 21$ & \\
\hline$=2 n x$ & $p==m s$ & II & $e \leq g e n v 21 u e$ & $a t a t \leq a t 10$ & value & \\
\hline 0 & 205 & 859.37638 & - & 154.7034 & 124.24 & \\
\hline 1 & 128 & 884.9703 & 0.49463 & 103.5156 & 94.13 & \\
\hline 2 & 229 & 901.41623 & 0.35503 & 70.6237 & 68.52 & \\
\hline 3 & 138 & 922.52055 & 0.25630 & 48.4252 & 47.21 & \\
\hline 4 & $24 \pi$ & 921.07037 & 0.20388 & 32.3252 & 29.68 & \\
\hline$s$ & 150 & 927.82104 & 0.16474 & 17.8141 & 25.42 & \\
\hline 6 & 153 & 933.16348 & 0.23283 & 7.2252 & 3.76 & \\
\hline 7 & 154 & 936.7282 & 0.09063 & & & \\
\hline
\end{tabular}

